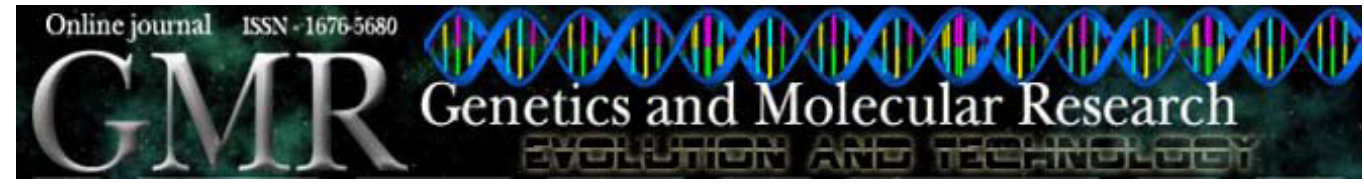

\title{
The L55M polymorphism of paraoxonase- 1 is a risk factor for rheumatoid arthritis
}

\author{
M. Hashemi ${ }^{1,2}$, A.K. Moazeni-Roodi ${ }^{3}$, A. Fazaeli ${ }^{4}$, M. Sandoughi ${ }^{5}$, M. Taheri ${ }^{6}$, \\ G.R. Bardestani ${ }^{5}$, Z. Zakeri ${ }^{5}$, D.M. Kordi-Tamandani ${ }^{7}$ and S. Ghavami ${ }^{8}$ \\ ${ }^{1}$ Department of Clinical Biochemistry, School of Medicine, \\ Zaedan University of Medical Sciences, Zahedan, Iran \\ ${ }^{2}$ Cellular and Molecular Research Center, \\ Zahedan University of Medical Sciences, Zahedan, Iran \\ ${ }^{3}$ Research Center for Infectious Diseases and Tropical Medicine, \\ Zahedan University of Medical Sciences, Zahedan, Iran \\ ${ }^{4}$ Department of Parasitology, School of Medicine, \\ Zanjan University of Medical Sciences, Zanjan, Iran \\ ${ }^{5}$ Department of Internal Medicine, School of Medicine, \\ Zahedan University of Medical Sciences, Zahedan, Iran \\ ${ }^{6}$ Department of Genetics, School of Medicine, \\ Zahedan University of Medical Sciences, Zahedan, Iran \\ ${ }^{7}$ Department of Biology, Faculty of Sciences, \\ University of Sistan and Baluchestan, Zahedan, Iran \\ ${ }^{8}$ Department of Physiology, Manitoba Institute of Child Health, \\ University of Manitoba, Winnipeg, Manitoba, Canada \\ Corresponding author: M. Hashemi \\ E-mail: mhd.hashemi@gmail.com / hashemim@zdmu.ac.ir
}

Genet. Mol. Res. 9 (3): 1735-1741 (2010)

Received April 30, 2010

Accepted June 24, 2010

Published August 31, 2010

DOI 10.4238/vo19-3gmr893

ABSTRACT. Paraoxonase-1 (PON1) is a high-density lipoprotein-
associated enzyme that exhibits antioxidant and antiatherogenic
activities. We examined a possible association between T172A
(L55M) and T(-107)C polymorphisms and rheumatoid arthritis. These
polymorphisms were determined in 88 rheumatoid arthritis patients and
78 healthy subjects, using the tetra-amplification refractory mutation
system-PCR method. The prevalence of the PON1 55MM genotype 
was significantly greater among rheumatoid arthritis patients $(17 \%)$ when compared to control subjects $(5.2 \%)$ (odds ratio $(\mathrm{OR})=3.75$; $95 \%$ confidence interval $(\mathrm{CI})=1.87-11.8, \mathrm{P}=0.025)$. In addition, the $\mathrm{M}$ allele was more frequent in rheumatoid arthritis patients $(40 \%)$ than in healthy subjects $(24.7 \%)(\mathrm{OR}=1.997 ; 95 \% \mathrm{CI}=1.243-3.210$, $\mathrm{P}=0.005$ ). There were no significant differences in the $-107 \mathrm{C} / \mathrm{T}$ polymorphism in the promoter sequence of PON1 between rheumatoid arthritis and normal subjects $\left(\chi^{2}=0.861, \mathrm{P}=0.650\right)$. In conclusion, the PON1 55MM genotype is a risk factor for rheumatoid arthritis.

Key words: Rheumatoid arthritis; L55M polymorphism; PON1; Paraoxonase

\section{INTRODUCTION}

Rheumatoid arthritis (RA) is a chronic inflammatory disease of unknown etiology affecting synovial membranes of multiple joints. Both genetic and environmental factors contribute to its etiopathogenesis (Deighton and Walker, 1991). It has been reported that reactive oxygen species (ROS) may play an important role in the pathogenesis of RA (Gambhir et al., 1997; Bauerova and Bezek, 1999). Under normal conditions, ROS are formed in oxidative processes at relatively low concentrations in all cells and tissues, and a variety of antioxidative mechanisms serve to control its production. Under pathological conditions, the levels of ROS are altered by increased production and/or inadequate removal, which results in oxidative stress, inducing cell damage and lipid peroxidation (Halliwell, 1994; Gambhir et al., 1997). Lipid peroxidation is a well-known mechanism of cellular damage in humans, and is used as an indicator of oxidative stress in cells and tissues.

Paraoxonase-1 (PON1) is coded by a gene located on chromosome 7q21.3-22.1 in a cluster with two similar genes, PON2 and PON3, whose physiological substrates are not yet recognized (Primo-Parmo et al., 1996). The 354-amino acid PON1 protein is exclusively bound to high-density lipoprotein. PON1 is recognized as an antioxidant enzyme as it hydrolyses lipid peroxides in oxidized lipoproteins (Blatter et al., 1993; Mackness et al., 1996; Aviram et al., 1998). PON1 also exerts paraoxonase and arylesterase activities, where it hydrolyzes organophosphates (paraoxon) and aromatic esters such as phenyl acetate (Gan et al., 1991).

It has been found that PON1 activity decreases in RA because of oxidative stress (Baskol et al., 2005; Isik et al., 2007). Paraoxonase activity is found to be comprehensively different among individuals, in part, as a result of the presence of polymorphisms. Two common coding region polymorphisms of PON1 (Q192R and L55M) lead to a change of both level and activity of the enzyme (Humbert et al., 1993; Garin et al., 1997; Mackness et al., 1998; Aviram et al., 2000). In addition, three polymorphic sites have been reported: T(-107)C, $\mathrm{G}(-824) \mathrm{A}$, and $\mathrm{G}(-907) \mathrm{C}$ in the promoter region of PON1, which affects gene expression and serum concentrations, in particular the $\mathrm{T}(-107) \mathrm{C}$ site (Leviev and James, 2000).

The data regarding PON1 Q192R polymorphisms in RA are controversial (Tanimoto et al., 2003; Hashemi et al., 2010). To the best of our knowledge there have been no reports investigating the PON1 T172A (L55M) and -107C/T polymorphisms in RA. We aimed to discover an association between T172A (L55M) and -107C/T polymorphism and RA. 


\section{MATERIAL AND METHODS}

\section{Patients}

The study project was approved by the Ethics Committee of the Zahedan University of Medical Sciences and informed consent was taken from all participants. A total of 88 patients ( 80 women and 8 men) with an average age of 45.5 years (minimum 17, maximum 75) fulfilling American College of Rheumatology criteria for RA were examined (Arnett et al., 1988). The control group consisted of 78 healthy individuals (59 women and 19 men) with a mean age of 45.5 years (minimum 23, maximum 77), who were unrelated to RA patients. Blood samples were collected in Na-EDTA tubes from patients and healthy controls and stored at $-20^{\circ} \mathrm{C}$ until DNA extraction.

\section{DNA extraction}

Two milliliters peripheral venous blood was collected from each subject for genomic DNA extraction as described previously (Hashemi et al., 2010).

\section{Tetra-primer amplification refractory mutation system}

Tetra-primer amplification refractory mutation system (ARMS) was designed for the detection of T172A (L55M) polymorphism and of -C107T PON1 according to the Ye et al. (2001) procedure. The primers used are shown in Table 1.

\begin{tabular}{l}
\multicolumn{3}{l}{ Table 1. Primers used for determination of -107C/T and PON1 L55M gene polymorphism. } \\
\begin{tabular}{lll}
\hline Primers & -107C/T & L55M \\
\hline Forward outer & 5'-GCCAGTCCCATCCCCAAGAGGGTGAGCG-3' & 5'-GGCTTTTGTACGTTTTGTG-3' \\
Reverse outer & 5'-GAAAGTGCTGAGCTCCTGCGGTGGGGGC-3' & 5'-CCGAAGAACACAAATATGCA-3' \\
Forward inner & 5'-AGCGCCGATTGGCCGCCACG-3' & 5'-CAGAAACTGGCTCTGAAGTCA-3' \\
Reverse inner & 5'-CTGCCGACCCGGCGGGGAGGTGT-3' & 5'-TCCATTAGGCAGTATCTCGAA-3' \\
\hline
\end{tabular}
\end{tabular}

Polymerase chain reaction (PCR) was performed using commercially available PCR premix (AccuPower PCR PreMix, BIONEER, Daejeon, South Korea) according to the manufacturer recommended protocol. Into a 0.2-mL PCR tube containing the AccuPower PCR PreMix, $1 \mu \mathrm{L}$ template DNA $(\sim 100 \mathrm{ng} / \mu \mathrm{L}), 1 \mu \mathrm{L}$ of each primer $(10 \mu \mathrm{M})$ and $15 \mu \mathrm{L}$ DNase-free water were added. The total volume for the PCR was $20 \mu \mathrm{L}$.

For detection of L55M polymorphism, PCR cycling conditions were as follows: $5 \mathrm{~min}$ at $95^{\circ} \mathrm{C} ; 30$ cycles of $30 \mathrm{~s}$ at $95^{\circ} \mathrm{C}, 30 \mathrm{~s}$ at $59^{\circ} \mathrm{C}$ and $40 \mathrm{~s}$ at $72^{\circ} \mathrm{C} ; 10 \mathrm{~min}$ at $72^{\circ} \mathrm{C}$ (Corbett Research, Australia). Each reaction was verified on a $\%$ agarose gel. Product sizes were: $262 \mathrm{bp}$ for the A allele (allele M), $351 \mathrm{bp}$ for the T allele (allele L), and $571 \mathrm{bp}$ for the two outer primers (Figure 1A).

For determination of $-107 \mathrm{C} / \mathrm{T}$ polymorphism, PCR cycling parameters were $5 \mathrm{~min}$ at $95^{\circ} \mathrm{C}$ followed by 25 cycles of $20 \mathrm{~s}$ at $95^{\circ} \mathrm{C}, 20 \mathrm{~s}$ at $66^{\circ} \mathrm{C}, 15 \mathrm{~s}$ at $72^{\circ} \mathrm{C}$ and $10 \mathrm{~min}$ at $72^{\circ} \mathrm{C}$ (Corbett Research). Product sizes were: $116 \mathrm{bp}$ for the $\mathrm{C}$ allele and $174 \mathrm{bp}$ for the $\mathrm{T}$ allele, while the product size of the two outer primers was $246 \mathrm{bp}$.

The statistical analysis of the data was performed using the SPSS 17.0 software. Genotypes and alleles between groups were compared by the $\chi^{2}$ test. 

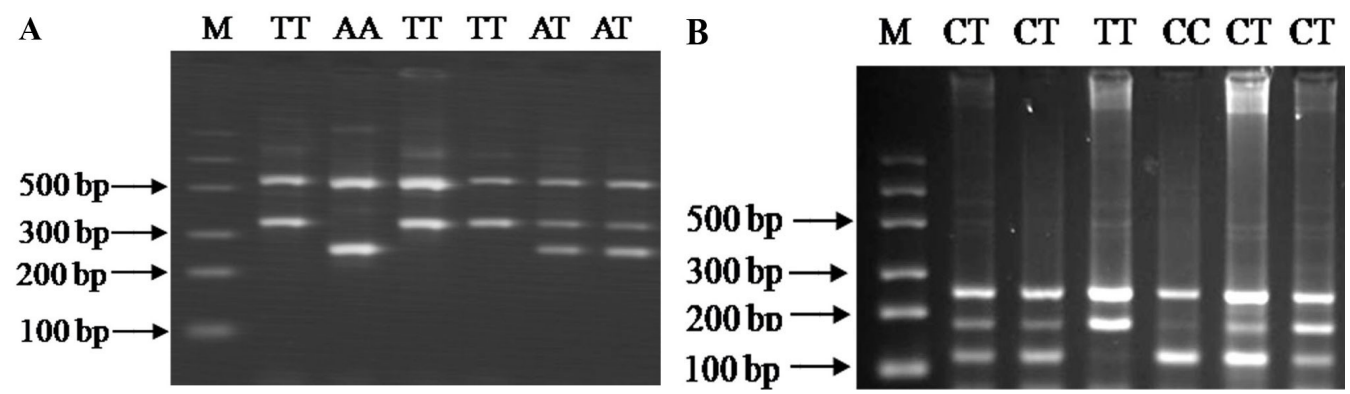

Figure 1. Results of tetra-ARMS-PCR of L55M (A) and (-107C/T) (B) of PON1 polymorphism. M = DNA marker.

\section{RESULTS}

\section{PON1 T172A (L55M) polymorphism}

The frequency of PON1 T172A (L55M) polymorphism in AR patients and normal subjects is shown in Table 2. The wild-type genotype (TT) was observed in 33/88 (37.5\%) of the patients; whereas 40/88 (45.5\%) were heterozygous (AT) and 15/88 (17\%) were homozygous (AA). In the control group, the frequencies of genotypes were $43 / 77(55.8 \%)$ for TT, $30 / 77$ (39.0\%) for AT and 4/77 (5.2\%) for AA. There were significant differences regarding PON1 T172A polymorphisms among RA patients and normal subjects $(\mathrm{P}<0.05)$.

Table 2. Genotype frequency of PON1 T172A (L55M) in rheumatoid arthritis (RA) patients and normal subjects.

\begin{tabular}{lcccr}
\hline Genotype & RA patients & Normal subjects & OR & $95 \%$ CI \\
\hline TT (LL) & $33 / 38(37.5 \%)$ & $43 / 77(55.8 \%)$ & 0.516 & $0.279-0.956$ \\
AT (LM) & $40 / 88(45.5 \%)$ & $30 / 77(39.0 \%)$ & 1.306 & $0.701-2.430$ \\
AA (MM) & $15 / 88(17.0 \%)$ & $4 / 77(5.2 \%)$ & 3.750 & $1.870-11.84$ \\
\hline
\end{tabular}

$\mathrm{OR}=$ odds ratio $; 95 \% \mathrm{CI}=$ confidence interval at $95 \%$.

As illustrated in Table 3, the prevalence of the $55 \mathrm{M}$ allele was significantly higher in RA patients $(39.8 \%)$ than in healthy subjects $(24.7 \%$ ) (odds ratio $=1.997,95 \%$ confidence interval $=1.243-3.210, \mathrm{P}=0.005)$, which illustrates that the $55 \mathrm{M}$ genotype is a risk factor for RA.

Table 3. Allele frequency of PON1 T172A (L55M) in rheumatoid arthritis (RA) patients and normal subjects.

\begin{tabular}{lrrrr}
\hline Allele type & RA patients & Normal subjects & OR & $95 \%$ CI \\
\hline T allele (L allele) & $106 / 176(60.2 \%)$ & $116 / 154(75.3 \%)$ & 0.491 & $0.308-0.797$ \\
A allele (M allele) & $70 / 176(39.8 \%)$ & $38 / 154(24.7 \%)$ & 1.997 & $1.243-3.210$ \\
\hline
\end{tabular}

$\mathrm{OR}=$ odds ratio; $95 \% \mathrm{CI}=$ confidence interval at $95 \%$.

\section{PON1 -107C/T polymorphism}

The distribution of PON1 -107C/T polymorphism in AR patients and normal subjects is shown in Table 4. No significant differences were observed among AR and control subjects 
regarding PON1 $-107 \mathrm{C} / \mathrm{T}$ polymorphism $\left(\chi^{2}=0.861, \mathrm{P}=0.650\right)$. The results indicated that there was no association between $-107 \mathrm{C} / \mathrm{T}$ PON1 polymorphism and AR.

Table 4. Distribution of PON1 -107C/T polymorphism in rheumatoid arthritis (RA) patients and normal subjects.

\begin{tabular}{lcc}
\hline Genotype & RA patients & Normal subjects \\
\hline CC & $25 / 88(28.4 \%)$ & $20 / 75(26.7 \%)$ \\
CT & $41 / 88(46.6 \%)$ & $40 / 75(53.3 \%)$ \\
TT & $22 / 88(25.0 \%)$ & $15 / 75(20.0 \%)$ \\
\hline
\end{tabular}

$\chi^{2}=0.861 ; P=0.650$.

There was no association between combined genotype polymorphism $(55 \mathrm{~L} / \mathrm{M}+$ $-170 \mathrm{C} / \mathrm{T}$ ) and AR (Table 5).

Table 5. Combined genotype polymorphism of PON1 in rheumatoid arthritis (RA) patients and normal subjects.

\begin{tabular}{lccc}
\hline & Genotype & & Group \\
\cline { 3 - 4 } & & RA patients & Normal subjects \\
\hline $55 \mathrm{~L} / \mathrm{M}$ & $-170 \mathrm{C} / \mathrm{T}$ & $13(14.8 \%)$ & $16(21.6 \%)$ \\
LL & CC & $15(17 \%)$ & $17(23 \%)$ \\
LL & CT & $5(5.7 \%)$ & $8(10.8 \%)$ \\
LL & TT & $9(10.2 \%)$ & $3(4.1 \%)$ \\
LM & CC & $20(22.7 \%)$ & $20(27 \%)$ \\
LM & CT & $11(12.5 \%)$ & $6(8.1 \%)$ \\
LM & TT & $3(3.4 \%)$ & $1(1.4 \%)$ \\
MM & CC & $6(6.8 \%)$ & $2(2.7 \%)$ \\
MM & CT & $6(6.8 \%)$ & $1(1.4 \%)$ \\
MM & TT & &
\end{tabular}

$\chi^{2}=11.04 ; \mathrm{P}=0.199$.

\section{DISCUSSION}

Studies have demonstrated that PON1 gene polymorphisms cause a change from glutamine to arginine at the 192 position, leucine to methionine at the 55 position and $\mathrm{T}(-107)$ $\mathrm{C}$ in the promoter region of PON1, altering both level and activity of the enzyme (Humbert et al., 1993; Garin et al., 1997; Mackness et al., 1998; Aviram et al., 2000; Leviev and James, 2000). In the present study, we found significant differences between RA and control subjects regarding T172A (L55M) polymorphism. The frequency of the AA genotype (MM allele) was significantly higher in RA patients than in normal subjects. In addition the A allele (allele M) was detected more frequently in RA versus controls. No association was observed between $\mathrm{T}(-107) \mathrm{C}$ single-nucleotide polymorphism in the promoter region of PON1 and RA.

In RA, increased ROS and production of lipid peroxidation, owing to synovial inflammation not only causes cellular damage, but also increases oxidative stress. In RA cases, increased oxidative stress and a decrease in antioxidants may have roles in both the pathogenesis of the disease (Nurcombe et al., 1991; Griffiths and Lunec, 1996) and the development of atherosclerosis (Sattar et al., 2003). Studies have shown that antioxidants are reduced in RA cases (McKeown et al., 1984; Jaswal et al., 2003; Isik et al., 2007). It has also been reported that there is an increase in the production of many cytokines, including tumor necrosis factor alpha (TNF- $\alpha$ ) and interleukin-1 in the inflamed joints of RA cases (Ridderstad et al., 1991; Zwerina et al., 2005). Increased TNF- $\alpha$ increases the endogenous level of ROS production and contributes to oxidative stress (Miesel et al., 1996). Anti-inflammatory therapy with TNF- $\alpha$ 
inhibitors has been shown to improve PON1 activity in RA patients (Popa et al., 2009).

Serum paraoxonase is an antioxidant enzyme because it hydrolyses lipid peroxides in oxidized lipoproteins (Mackness et al., 1996; Aviram et al., 1998). PON1 hydrolyses lipid peroxidation products and $\mathrm{H}_{2} \mathrm{O}_{2}$ (Feingold et al., 1998) and contributes to the prevention of low-density lipoprotein oxidation (Miesel et al., 1996; Mackness et al., 1998; Shih et al., 1998; Popa et al., 2009). An inverse association between PON1 activity and oxidative stress in serum and macrophages has been suggested (Rozenberg et al., 2003). It has been reported that serum PON1 activity decreased significantly in RA patients compared with healthy individuals (Maury et al., 1984; Tanimoto et al., 2003; Baskol et al., 2005).

There is some evidence showing an association between T172A (L55M) polymorphism and plasma PON1 activity. Garin et al. (1997) showed that the 55L allele (172T allele) has significantly higher concentrations of paraoxonase than the 55M allele (172A allele). Furthermore, Leviev et al. (1997) have found a significantly higher concentration of the L-type mRNA expression than the M-type in liver samples, supporting the idea that higher concentrations of serum paraoxonase are expressed in the $\mathrm{L}$ allele compared to the $\mathrm{M}$ allele.

In conclusion, we found that there is an association between PON1 L55M polymorphism and RA. No association was observed between T(-107)C single-nucleotide polymorphism in the promoter region of PON1 and RA. To the best of our knowledge, this study is important as it demonstrates the relationship of PON1 L55M polymorphisms and RA for the first time.

\section{ACKNOWLEDGMENTS}

The authors thankfully acknowledge Zahedan University of Medical Sciences for grant support. In addition, the authors would like to thank the patients and healthy subjects who willingly participated in the study.

\section{REFERENCES}

Arnett FC, Edworthy SM, Bloch DA, McShane DJ, et al. (1988). The American Rheumatism Association 1987 revised criteria for the classification of rheumatoid arthritis. Arthritis Rheum. 31: 315-324.

Aviram M, Rosenblat M, Bisgaier CL, Newton RS, et al. (1998). Paraoxonase inhibits high-density lipoprotein oxidation and preserves its functions. A possible peroxidative role for paraoxonase. J. Clin. Invest. 101: 1581-1590.

Aviram M, Hardak E, Vaya J, Mahmood S, et al. (2000). Human serum paraoxonases (PON1) Q and R selectively decrease lipid peroxides in human coronary and carotid atherosclerotic lesions: PON1 esterase and peroxidase-like activities. Circulation 101: 2510-2517.

Baskol G, Demir H, Baskol M, Kilic E, et al. (2005). Assessment of paraoxonase 1 activity and malondialdehyde levels in patients with rheumatoid arthritis. Clin. Biochem. 38: 951-955.

Bauerova K and Bezek A (1999). Role of reactive oxygen and nitrogen species in etiopathogenesis of rheumatoid arthritis. Gen. Physiol. Biophys. 18 (Spec No.): 15-20.

Blatter MC, James RW, Messmer S, Barja F, et al. (1993). Identification of a distinct human high-density lipoprotein subspecies defined by a lipoprotein-associated protein, K-45. Identity of K-45 with paraoxonase. Eur. J. Biochem. 211: 871-879.

Deighton CM and Walker DJ (1991). The familial nature of rheumatoid arthritis. Ann. Rheum. Dis. 50: 62-65.

Feingold KR, Memon RA, Moser AH and Grunfeld C (1998). Paraoxonase activity in the serum and hepatic mRNA levels decrease during the acute phase response. Atherosclerosis 139: 307-315.

Gambhir JK, Lali P and Jain AK (1997). Correlation between blood antioxidant levels and lipid peroxidation in rheumatoid arthritis. Clin. Biochem. 30: 351-355.

Gan KN, Smolen A, Eckerson HW and La Du BN (1991). Purification of human serum paraoxonase/arylesterase. Evidence for one esterase catalyzing both activities. Drug Metab. Dispos. 19: 100-106. 
Garin MC, James RW, Dussoix P, Blanche H, et al. (1997). Paraoxonase polymorphism Met-Leu54 is associated with modified serum concentrations of the enzyme. A possible link between the paraoxonase gene and increased risk of cardiovascular disease in diabetes. J. Clin. Invest. 99: 62-66.

Griffiths HR and Lunec J (1996). The C1q binding activity of IgG is modified in vitro by reactive oxygen species: implications for rheumatoid arthritis. FEBS Lett. 388: 161-164.

Halliwell B (1994). Free radicals, antioxidants, and human disease: curiosity, cause, or consequence? Lancet 344: 721-724.

Hashemi M, Moazeni-Roodi AK, Fazaeli A, Sandoughi M, et al. (2010). Lack of association between paraoxonase-1 Q192R polymorphism and rheumatoid arthritis in southeast Iran. Genet. Mol. Res. 9: 333-339.

Humbert R, Adler DA, Disteche CM, Hassett C, et al. (1993). The molecular basis of the human serum paraoxonase activity polymorphism. Nat. Genet. 3: 73-76.

Isik A, Koca SS, Ustundag B, Celik H, et al. (2007). Paraoxonase and arylesterase levels in rheumatoid arthritis. Clin. Rheumatol. 26: 342-348.

Jaswal S, Mehta HC, Sood AK and Kaur J (2003). Antioxidant status in rheumatoid arthritis and role of antioxidant therapy. Clin. Chim. Acta 338: 123-129.

Leviev I and James RW (2000). Promoter polymorphisms of human paraoxonase PON1 gene and serum paraoxonase activities and concentrations. Arterioscler. Thromb. Vasc. Biol. 20: 516-521.

Leviev I, Negro F and James RW (1997). Two alleles of the human paraoxonase gene produce different amounts of mRNA. An explanation for differences in serum concentrations of paraoxonase associated with the (Leu-Met54) polymorphism. Arterioscler. Thromb. Vasc. Biol. 17: 2935-2939.

Mackness B, Mackness MI, Arrol S, Turkie W, et al. (1998). Effect of the human serum paraoxonase 55 and 192 genetic polymorphisms on the protection by high density lipoprotein against low density lipoprotein oxidative modification. FEBS Lett. 423: 57-60.

Mackness MI, Mackness B, Durrington PN, Connelly PW, et al. (1996). Paraoxonase: biochemistry, genetics and relationship to plasma lipoproteins. Curr. Opin. Lipidol. 7: 69-76.

Maury CP, Junge W and Teppo AM (1984). Serum esterase activity in reactive systemic amyloidosis and its relation to amyloid A degrading activity. J. Lab. Clin. Med. 104: 761-766.

McKeown MJ, Hall ND and Corvalan JR (1984). Defective monocyte accessory function due to surface sulphydryl (SH) oxidation in rheumatoid arthritis. Clin. Exp. Immunol. 56: 607-613.

Miesel R, Murphy MP and Kroger H (1996). Enhanced mitochondrial radical production in patients which rheumatoid arthritis correlates with elevated levels of tumor necrosis factor alpha in plasma. Free Radic. Res. 25: 161-169.

Nurcombe HL, Bucknall RC and Edwards SW (1991). Activation of the neutrophil myeloperoxidase- $\mathrm{H}_{2} \mathrm{O}_{2}$ system by synovial fluid isolated from patients with rheumatoid arthritis. Ann. Rheum. Dis. 50: 237-242.

Popa C, van Tits LJ, Barrera P, Lemmers HL, et al. (2009). Anti-inflammatory therapy with tumour necrosis factor alpha inhibitors improves high-density lipoprotein cholesterol antioxidative capacity in rheumatoid arthritis patients. Ann. Rheum. Dis. 68: 868-872.

Primo-Parmo SL, Sorenson RC, Teiber J and La Du BN (1996). The human serum paraoxonase/arylesterase gene (PON1) is one member of a multigene family. Genomics 33: 498-507.

Ridderstad A, Abedi-Valugerdi M and Moller E (1991). Cytokines in rheumatoid arthritis. Ann. Med. 23: 219-223.

Rozenberg O, Rosenblat M, Coleman R, Shih DM, et al. (2003). Paraoxonase (PON1) deficiency is associated with increased macrophage oxidative stress: studies in PON1-knockout mice. Free Radic. Biol. Med. 34: 774-784.

Sattar N, McCarey DW, Capell H and McInnes IB (2003). Explaining how "high-grade" systemic inflammation accelerates vascular risk in rheumatoid arthritis. Circulation 108: 2957-2963.

Shih DM, Gu L, Xia YR, Navab M, et al. (1998). Mice lacking serum paraoxonase are susceptible to organophosphate toxicity and atherosclerosis. Nature 394: 284-287.

Tanimoto N, Kumon Y, Suehiro T, Ohkubo S, et al. (2003). Serum paraoxonase activity decreases in rheumatoid arthritis. Life Sci. 72: 2877-2885.

Ye S, Dhillon S, Ke X, Collins AR, et al. (2001). An efficient procedure for genotyping single nucleotide polymorphisms. Nucleic Acids Res. 29: E88.

Zwerina J, Redlich K, Schett G and Smolen JS (2005). Pathogenesis of rheumatoid arthritis: targeting cytokines. Ann. N. Y. Acad. Sci. 1051: 716-729. 